\title{
Analysis of the Management of Higher Vocational Students in the Mode of Modern Apprenticeship
}

\author{
Xiaoxue Xiang \\ Xiangyang Vocational and Technical College, Xiangyang, Hubei, 441000
}

Keywords: Modern Apprenticeship, Vocational Education, Student Management.

\begin{abstract}
In the current vocational colleges, in order to be able to better cultivate the management of the work, began to change the new teaching model, that is, modern apprenticeship model. Modern apprenticeship model is a combination of work and teaching teaching mode, in practical application can effectively improve the student's self-management. So more and more vocational colleges began to apply the modern apprenticeship model in the management of students. Based on this, this article on the current modern apprenticeship model under the vocational management of students focus on the discussion and analysis.
\end{abstract}

\section{Introduction}

Through the practice shows that the apprenticeship in the work can play an important role, especially for the new staff into the work, as well as master the skills to play a good effect. In recent years, with the continuous reform of the education system, more and more vocational colleges began to use the characteristics of modern apprenticeship, in the actual teaching application apprenticeship model. This teaching method, not only to a certain extent, so that students in the education at the same time with the modern society, but also with the current skills to adapt to the concept of talent.

\section{The modern apprenticeship of the connotation, characteristics and advantages}

Generally speaking, the modern apprenticeship system refers to the master of the apprentice's comprehensive education and full guidance, modern apprenticeship model and the traditional apprenticeship there is a certain difference, embodied in the subject, form, system and division Health relations these aspects $\{1\}$. In the actual performance of the following aspects: First, identity. In the modern apprenticeship model, learners have two identities, namely apprenticeship and student ID. The whole kind of identity is not only professional practice master guidance, there are special school professor; the second is to cultivate goals. The application of modern apprenticeship model in higher vocational teaching is to cultivate the applied talents with both theoretical knowledge and professional practical ability. Thirdly, the place of study, for the modern apprenticeship, the main emphasis is on the real production Places and schools to learn at the same time; Fourth, the assessment methods. In practical applications, the assessment of modern apprenticeship model requires not only the evaluation of teachers and teachers, but also the evaluation of schools and the education sector.

For the apprenticeship, it is required to apprentice to the side of the operation, or industry can first operate in the study of relevant theoretical knowledge, that is, "do secondary school" $\{2\}$. Through the students on the early observation, in the process of continuous operation and training, in order to master the steps of the operation.

As a vocational college, in the modern apprenticeship model, so that students in the real work environment to learn, to better learn their knowledge and skills applied in practice. In addition, in practice, students can gradually grasp the relevant rules and methods, and then be able to gradually complete the work required for the work attitude and way of thinking. In which, through the master or other predecessors of the observation. 
For the individualized teaching, it is in the concept of Confucius and the teaching of the individual has some similarities, in practical application, mainly based on the learner's personality to create targeted learning plan, and can respect each individual's personality $\{3\}$. The modern apprenticeship model is to use this way to the hands of the form, so that the master better understand the apprentice personality and the actual learning situation.

As we all know, the modern apprenticeship training model is developed by the industry practitioners qualifications and standards, schools and enterprises co-cultivation, while the government as an important support and protection $\{4\}$. The current apprenticeship system is a kind of teaching mode which can meet the needs of the market. It can show the demand of different practitioners in different industries according to the actual situation. Therefore, in order to be able to better enable students to meet the requirements of practitioners, the school will need to work experience and the required theoretical knowledge of the combination of learning, so as to make vocational colleges become vocational education and training starting point.

The ability to effectively improve the employment rate of young people is mainly reflected in the following aspects: First, the application of modern apprenticeship can better help students to work smoothly, and make it able to adapt to the changes in the identity of office workers. Second, in the current apprenticeship model, students can have more opportunities to stay in the training of enterprises engaged in practice $\{5\}$. In the enterprise practice, to clearly understand the skills required for the work, and can quickly adapt to the enterprise environment, so that not only can help enterprises to reduce the training of new employees, but also to better promote the development of enterprises.

For higher vocational colleges, it is in the nature of education is a supply-oriented planning model. The institutions through the demand for talent forecast, combined with the market to targeted training personnel. However, due to the potential risks associated with the relevant information, it will lead to the unbalanced supply of schools in the vocational education led to the emergence of structural unemployment. In view of this situation, the school will be able to use modern apprenticeship to avoid.

\section{The modern apprenticeship model of vocational students under the management of the problems}

Under the modern apprenticeship model, the problems in the management of higher vocational students mainly include the following aspects:

At this stage, vocational students in the modern apprenticeship mode of management, the first problem is to face teaching management. In the actual teaching management model, the relationship between the relevant theory and practice has been seriously fragmented. The relationship between theory and practice is mainly for the cultivation of vocational colleges in terms of $\{6\}$. In the vocational colleges to carry out targeted apprenticeship education, not only to cultivate professional skills of talent, but also to be able to better help students in a short time to achieve their own hands to enhance the purpose of the ability. But in practice, most vocational students in the teaching management work, the school pay more attention to learning research courses, and to instill more theoretical knowledge of students, which will easily overlook the apprenticeship education model.

In the modern apprenticeship model, between the school and the business, students are taking different responsibilities. Because of the large difference in the environment between enterprises and schools, the interpersonal relationship faced by enterprises is more complicated than that of schools. Secondly, the actual management methods of vocational colleges are obviously different from those of enterprises. In this form, the students after entering the enterprise is very susceptible to different factors and the emergence of work retreat, a sufficient phenomenon. If the vocational colleges in the process of student development does not pay attention to the ideological and political work of students, it will certainly affect the development of students $\{7\}$. In this regard, higher vocational colleges in the modern apprenticeship model, to carry out student management, we must pay attention to the ideological and political work of students, so not only to a certain extent, improve the efficiency of student management, but also to further enhance the students' 
Psychological quality and affordability, and thus promote the school, students and enterprises to common progress and development.

Modern apprenticeship model, greatly reducing the time students in school, the longer the students work in the enterprise, the school's teaching model of the students will continue to reduce the influence. The main reason for this situation is the lack of a certain form of communication and communication between vocational schools and enterprises, and thus to a large extent affect the development of student management and carried out $\{8\}$. With the advancement of education reform in our country, as a vocational college, in order to further promote the ability and level of student management work, we must first take the initiative to explore the communication path with the enterprise and the specific form of communication in order to better achieve The purpose of good communication between enterprises, through this way not only to break the modern apprenticeship model to vocational college students management work set obstacles, but also to better promote the management of vocational students in the progress and development.

\section{The modern apprenticeship model of vocational students under the new path of management}

As a vocational college, in order to be able to play a better role in the system of modernized apprenticeship, we must be able to further find a new path for the management of vocational students, the only way to better achieve the goal of personnel training.

Modern apprenticeship model, mainly school-enterprise cooperation and work combined with the talent training model, this model, the need for both schools and universities to bear the responsibility of training professional skills, while taking responsibility for management of students (apprentices). So it is necessary to establish and improve the relevant rules and regulations. The school can be based on the actual situation to establish a special counselor system, mainly for students of ideological and political, professional ethics and social responsibility of education, etc .; Second, establish and improve the student's work management system, in the process for students to set up a special work management And the establishment of student records management, which can make the school regularly check the situation of students apprentices, and thus ensure the normal development of modern apprenticeship; Finally, vocational colleges also in their own, business and parental responsibility, rights and obligations On the basis of the establishment of a tripartite information reporting system $\{9\}$. In this way, not only can the student apprenticeship management work, but also to further improve the level of student management.

In order to be able to better carry out student management work, as a vocational college, need to change the past only focus on theoretical knowledge to teach and ignore the practice of training mode. In this regard, the school needs in the modern apprenticeship model, adhere to the "student-oriented" education concept, pay attention to cultivate students self-confidence, self-reliance and self-improvement learning attitude, and continuously improve the students' self-education and self-management and purple service Ability; In addition, we must establish a student "dynamic service" management philosophy, in schools, enterprises in the students to provide ideological guidance and psychological counseling and other related services. At the same time, vocational colleges should strengthen cooperation with enterprises, and strive to solve their problems in the modern apprenticeship model of personnel training in order to be able to better cultivate professional talents.

As we all know, modern apprenticeship is the current vocational colleges to implement school-enterprise cooperation and an important means of combining work and study, but also vocational students to implement professional quality education an important way. In today's business, in the talent needs to be able to grasp the relevant technical skills, but also have a certain degree of professional ethics and professionalism. Thus in this regard, the school should be able to give enough attention $\{10\}$. In the implementation of the method, the school can invite the more excellent management personnel to students for professional etiquette and professional ethics training, in addition, you can also use the students in the production line and the master of the direct exchange and contact opportunities The students of the appropriate vocational skills and professionalism of the integration of training. 
In the process of student training, schools and enterprises must follow the relevant provisions and standards to students pre-job safety education, the reason is mainly to avoid the lack of safety awareness of students due to safety accidents. In this regard, vocational institutions and managers of the relevant managers, to students in practice, do a good job of the corresponding safety education. This will not only improve the students' self-protection and self-help ability in practice, but also can guarantee the effectiveness of vocational colleges in the modern apprenticeship mode.

\section{Conclusion}

In order to improve the ability and level of students' management, we should pay attention to the problems existing in the management of higher vocational students under the modern apprenticeship model, and be able to take positive ones in the modern apprenticeship model. Effective measures to solve, the only way to better meet the current needs of education reform. For how to further improve the management of vocational students, the school can be carried out in accordance with the above way, that is, to improve the relevant rules and regulations, change the students education and management ideas, and the rational use of modern apprenticeship, comparative students comprehensive quality education (vocational quality education , Labor safety education). Through these methods, we can find a new path of student management in modern apprenticeship model, and not only can we achieve the goal of modern apprenticeship training, but also help students find the correct direction of life and promote their all - round development.

\section{References}

[1] Li Shouzhi, Lu Jiande. Modern apprenticeship theory and practice personnel training in higher vocational colleges [J]. Modern Apprenticeship Education in Higher Vocational Colleges, 2014 (23).

[2] Liu Jianying, Song Peng.Discussion on modern apprenticeship modern apprenticeship model in higher vocational colleges [J]. Journal of Liaoning Higher Vocational College, 2012 (3)

[3] Li Xiang. Modern apprenticeship model under the management of vocational students [J]. Education Exploration, 2015, 0 8: 52 - 54.

[4] Qiao Weili. Modern apprenticeship under the new vocational management model [J]. Test Weekly, 2015,52:142-133

[5] Ma Xiaofeng. Modern apprenticeship system under the vocational management model [J]. Hebei Energy Vocational and Technical College, 2014 (1):10-12.

[6] Zhong Yinzhen, Gao Weichun. Journal of Anhui Vocational College of Electronics and Information Technology, 2014 (1): 101-103. Journal of Anhui Vocational College of Electronics and Information Technology, 2014 (1): 101-103.

[7] Liu Haitao.Study on the Management of Higher Vocational Students under the Mode of Combining Talents with Work and Study [J]. Vocational Education Research, 2012 (9): 46-47.

[8] Hou Meiling.Study on the management of higher vocational students in modern apprenticeship model [J]. Journal of Jiamusi Vocational College, 2016,03: 38.

[9] Dang Siqi. Study on the Management of Students in Higher Vocational Colleges under the Modern Apprenticeship Model [J]. Journal of Industry and Technology, 2017, 11: 244-245.

[10] Jiang Libo. The modern apprenticeship system to adapt to the student management work model [J]. Liaoning Vocational Journal, 2016,10: 81-83. 